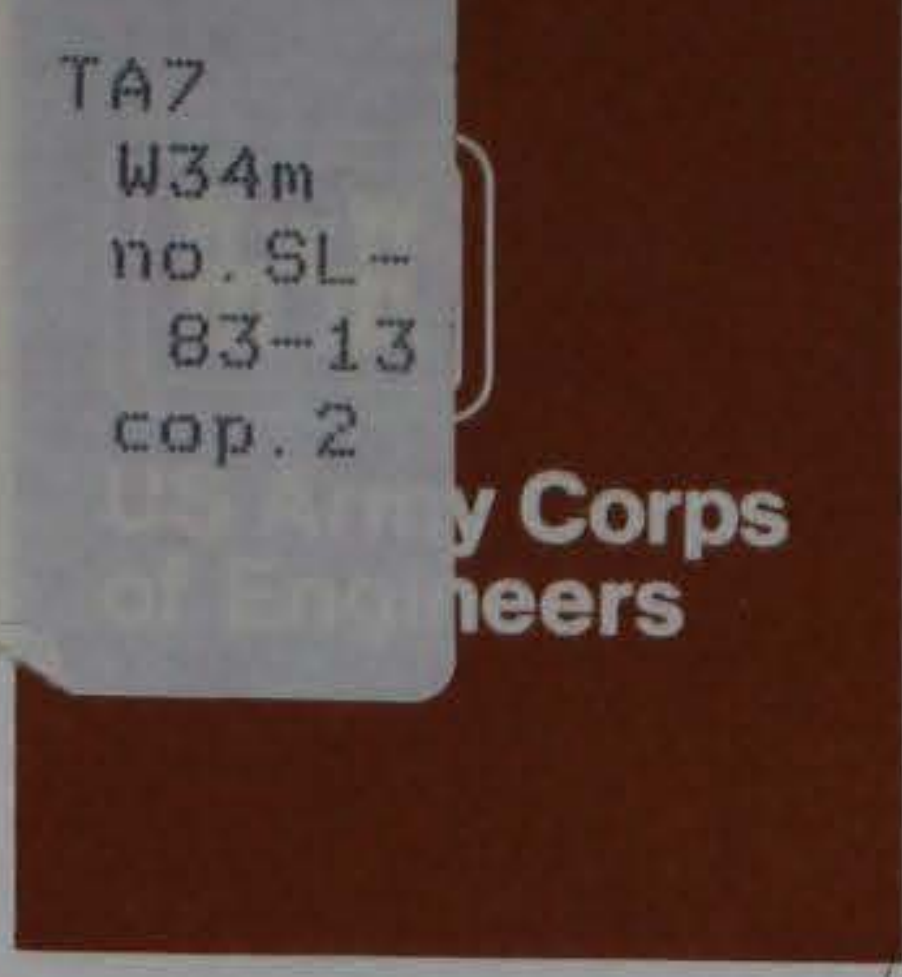

US-CE-CProperty of the Uniled Stalea Government MISCELLANEOUS PAPER SL-83-13

\title{
ALKALI REACTIVITY OF STRAINED QUARTZ AS A CONSTITUENT OF CONCRETE AGGREGATE
}

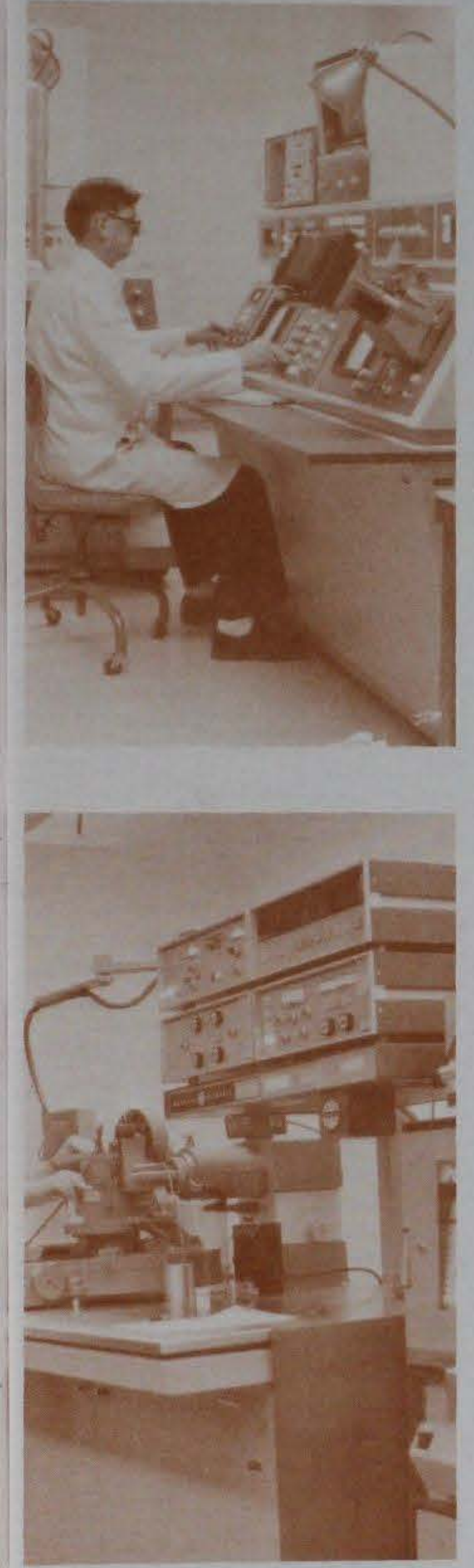

by

Alan

D. Buck

Structures Laboratory

U. S. Army Engineer Waterways Experiment Station P. O. Box 631, Vicksburg, Miss. 39180

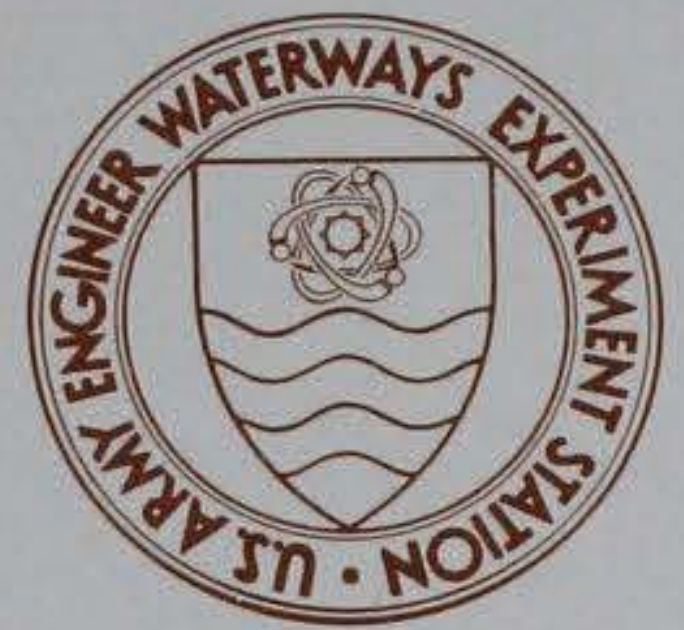

\section{August 1983 \\ Final Report}

Approved For Public Release; Distribution Unlimited

LIBRARY BRANCH

TECHINICAL INFORMATION CENTER

US ARMY ENGINEER WATERWAYS EXPERUAENT STATION VICKSBURG, MASSISSIPPI

Prepared for Office, Chief of Engineers, U. S. Army

Washington, D. C. 20314

Under CWIS Work Unit 31138 


\section{Preface}

This paper is based on portions of two projects dealing with alkalisilica reaction. One started as an In-House Laboratory Independent Research (ILIR) program titled "Reactivity of Quartz at Normal Temperatures"; it was later funded as an Army Research Office (ARO) - Durham project. The second project was Office, Chief of Engineers, Engineering Study Work Unit 31294, "Minimize Alkali-Silica Reaction." This work was done at the U. S. Army Engineer Waterways Experiment Station (WES) in the Concrete Technology Division (formerly Concrete Laboratory) of the Structures Laboratory under the direction of Messrs. B. Mather and J. M. Scanlon, Jr. Mrs. Katharine Mather was Project Leader. Mr. A. D. Buck prepared this paper as a contribution for the ASTM Journal, Cement, Concrete, and Aggregates.

The Concrete Technology Information and Analysis Center (CTIAC) provided funds to publish this report; it is CTIAC Report No. 65. COL Tilford C. Creel, CE, was Commander and Director of WES when this paper was prepared. Mr. F. R. Brown was Technical Director. 


\section{Contents}

$\underline{\text { Page }}$

Preface ....................... . . . . . 1

Background ..................... . . . . . 3

Materials and Methods .................. 4

Results........................ . . . . 4

Discussion . . . . . . . . . . . . . . . . 5

References . . . . . . . . . . . . . . . . 8

Tables 1-2

Figures 1-2 


\section{ALKALI REACTIVITY OF STRAINED QUARTZ}

\section{AS A CONSTITUENT OF CONCRETE AGGREGATE}

\section{Background}

Criteria exist for the recognition of forms of silica that would be expected to participate in the alkali-silica reaction. Those criteria have, in general, worked well. It has become increasingly obvious in recent years, particularly from reports by Buck and Mather; Mather; Buck and Burkes; Mather; and by Duncan, Swenson, Gillott, and Foran (1-5), that these criteria are not effective for all silica-bearing rocks. In fact, it was pointed out by Mielenz (6) as early as 1954 and by Brown (7) in 1955 that some quartz can be a reactive material in the alkali-silica reaction. Work done in the Structures Laboratory of the U. S. Army Engineer Waterways Experiment Station has verified the reactivity of strained quartz and quartzite in laboratory experiments. The key point in these examples of the reactivity of quartz or quartz-bearing rocks has been that the reaction was so slow that the effects of the reaction were not detected by existing test methods.

It is the purpose of this paper to present criteria for the recognition of potentially reactive strained quartz intended for use as concrete aggregate and to suggest revisions in existing documents to incorporate these new criteria.

It is believed that quartz is reactive in relation to its state of order-disorder and that increasing disorder leads to increasing reactivity. A further premise is that a distinction between reactive and innocuous quartz can be made on the basis of its undulatory extinction angle and expansion in mortar-bar tests. There was a relation between increasing storage temperature and increasing specimen expansion in these tests, and this difference is part of the proposed new criteria for recognizing strained quartz as potentially reactive. Lerch (8) and Sideris (9) have described an expansion maximum at around $40^{\circ} \mathrm{C}$. Duncan et al. (5) and we have found that there is more expansion with increasing temperature. The reason for this difference between researchers could be that there was a drying at higher temperatures in the other work which lessened expansion with increasing temperature. 


\section{Materials and Methods}

Eight natural gravels from the Atlantic Coastal Plain areas of North Carolina, South Carolina, Maryland, and Virginia were used. They were large quartz and quartzite particles. Such particles smaller than $19 \mathrm{~mm}$ (3/4 in.) and larger than the $12.5-\mathrm{mm}(1 / 2-i n$.$) sieve were sepa-$ rated; five or ten of these particles were embedded in mortar bars by hand, and the bars were tested for length changes at $37.8^{\circ} \mathrm{C}\left(100^{\circ} \mathrm{F}\right)$ and $60^{\circ} \mathrm{C}\left(140^{\circ} \mathrm{F}\right)$ for ages up to 4 years; these were ASTM C-109 mortars, "Standard Test Method for Compressive Strength of Hydraulic Cement Mortars," made with ottawa sand and high-alkali cements (>1 percent alkali as $\left.\mathrm{Na}_{2} \mathrm{O}\right)$. After exposure, these bars were examined for evidence of alkali-silica reaction. Thin sections of similar particles were made and examined to determine undulatory extinction angles by Mather (10). A reactive granite gneiss aggregate like that reported by Mather (2) was processed into sand and used in mortar bars that were measured at $37.8^{\circ} \mathrm{C}$ or $60^{\circ} \mathrm{C}$ for 2 years. These bars were made in accordance with ASTM C-227, "Standard Test Method for Potential Alkali Reactivity of Cement-Aggregate Combinations (Mortar-Bar Method)," with similar cement as above.

\section{$\underline{\text { Results }}$}

Table 1 shows length changes for mortar bars containing five embedded quartz or quartzite pebbles from one gravel at two temperatures for 4 years. Table 2 shows similar data to 2 years for the granite gneiss sand. The data in these tables indicate:

a. More expansion at $60^{\circ} \mathrm{C}$ than at $37.8^{\circ} \mathrm{C}$.

b. The bars containing granite gneiss sand and those containing quartz or quartzite pebbles show enough expansion to be considered reactive but not by the present time criteria of existing ASTM or Corps of Engineers' documents ("Standard Test Method for Potential Alkali Reactivity of CementAggregate Combinations (Mortar-Bar Method)," ASTM C 227-71; "Alkali-Silica Aggregate Reactions," Appendix B, Engineering and Design, Standard Practice for Concrete, EM 1110-22000, Office, Chief of Engineers). 
c. Expansions were similar for quartz and quartzite pebbles.

Particles from the seven other gravels showed expansions similar to those in Table 1. Comparison showed slightly more expansion with five than with ten embedded particles. A repeat mortar-bar test of one gravel using different quartz and quartzite pebbles showed similar results.

Figure 1 shows an example of alkali-silica reaction as evidenced by gel on a broken surface of a concrete core containing Sioux Quartzite; the reactivity of this aggregate was verified by unpublished laboratory testing of the Corps of Engineers Division Laboratory in Omaha.*

Examination of mortar bars containing quartz or quartzite pebbles after several years of testing showed slight but definite signs of alkali-silica reaction in bars kept at each temperature and with both types of pebbles. Alkali-silica gel was best seen on broken surfaces while reaction rims and cracks in the pebbles were more apparent on sawed and smoothed surfaces; all of these were signs of alkali-silica reaction in these bars. Figure 2 shows all of these features. The identification of alkali-silica gel was verified by examination of immersion mounts with a polarizing microscope.

\section{Discussion}

Gogte (11) was apparently the first to suggest that undulatory extinction angles of strained quartz could be used to indicate potential reactivity; he suggested that 20 percent of strained quartz in a rock was the minimum amount needed to develop significant reaction. As indicated earlier, K. Mather (10) measured undulatory extinction angles on thin sections of quartz and quartzite from the Atlantic Coastal Plain gravels; she reported values ranging from 36 to 64 degrees and speculated that these high values might mean that all of the gravels were reactive; this speculation was borne out by the length-change data and by the evidence of alkali-silica reaction in the bars. Dolar-Mantuani (12) provided more recent details on undulatory extinction angles; she discussed the need for better definition of how to measure these angles and the

* William Heck, personal communication. 
number of measurements needed. She also suggested that undulatory extinction angles smaller than 15 degrees indicate nonreactive rocks.

Based on these considerations, criteria for recognizing strained quartz as a potentially deleteriously alkali reactive aggregate constituent should define such material as quartz characterized by undulatory extinction angles greater than 15 degrees and should stipulate that more than 20 percent of strained quartz is required to classify a fine or coarse aggregate as potentially reactive. For such aggregates, a mortarbar test (ASTM C-227) should be made using sand or five embedded gravel particles per bar with testing at $60^{\circ} \mathrm{C}$ rather than at $37.8^{\circ} \mathrm{C}$. Lengthchange criteria to declare the aggregate potentially reactive are a minimum of 0.025 or 0.040 percent at 6 or 12 months, respectively; these values are only for aggregates containing strained quartz. The usual length-change values of 0.05 or 0.10 percent for other aggregates still apply.

Other changes that appear desirable include:

a. Modify the description of quartz under silica minerals in ASTM C-294* to say that some quartz is strained and may be reactive with the alkalies in portland cement paste. Specify that strained quartz in an aggregate is considered to cause the aggregate to be reactive when it amounts to at least 20 percent of the aggregate and has an average undulatory extinction angle that exceeds 15 degrees.

b. Modify paragraph 4.5 in ASTM C-295** by deleting "vein , quartz' and replacing it with the term "strained quartz."

c. Modify the comments about Recommended Practice C-295 in the Appendix of ASTM C-33t to include "strained quartz."

In regard to the whole subject of alkali-silica reaction, Stark (13) recently presented evidence for extending mortar-bar testing from 6 to 12 months. Tuthill (14) has suggested that the same change be at least considered. ASTM C-227 and the Appendix to ASTM C-33 both specify 0.05 and 0.10 percent expansion at 3 and 6 months, respectively, as critical

\footnotetext{
* "Standard Descriptive Nomenclature of Constituents of Natural Mineral Aggregates."

** "Standard Practice for Petrographic Examination of Aggregates for Concrete."

+ "Standard Specification for Concrete Aggregates."
} 
values. These should be changed to the same numerical values at 6 and 12 months for the reasons presented by Stark (13) and by Tuthill (14). 


\section{$\underline{\text { References }}$}

1. Buck, A. D. and Mather, K., "Concrete Cores from Dry Dock No. 2, Charleston Naval Shipyard, S. Carolina," U. S. Army Engineer Waterways Experiment Station, Miscellaneous Paper C-69-6, Vicksburg, Miss., Jun 1969.

2. Mather, K., "Examination of Cores from Four Highway Bridges in Georgia," U. S. Army Engineer Waterways Experiment Station, Miscellaneous Paper C-73-11, Vicksburg, Miss., Nov 1973.

3. Buck, A. D. and Burkes, J. P., "Alkali-Silica Reaction in Concrete from Hiwassee Dam, N. Carolina, Tennessee Valley Authority," U. S. Army Engineer Waterways Experiment Station, Miscellaneous Paper C-78-10, Vicksburg, Miss., Aug 1978.

4. Mather, K., "Condition of Concrete in Martin Dam After 50 Years of Service," Cement, Concrete, and Aggregates, CCAGDP, Vo1 3, No. 1, Summer 1981, pp 53-62.

5. Duncan, M. A. G., Swenson, E. G., Gillott, J. E., and Foran, M. R., "Alkali-Aggregate Reaction in Nova Scotia, Parts I-III, Part IV (without Foran)," Cement and Concrete Research, Vol 3, No. 1, pp 5567, No. 2, pp 119-128, No. 3, pp 233-245, and No. 5, pp 521-535, 1973.

6. Mielenz, R. C., "Petrographic Examination of Concrete Aggregate," ASTM Proc. 54, 1954, pp 1188-1218.

7. Brown, L. S., "Some Observations on the Mechanics of Alkali-Aggregate Reaction," ASTM Bulletin 205, 1955, pp 40-56.

8. Lerch, W., "Chemical Reactions" in Significance of Tests and Properties of Concrete and Concrete Aggregates, ASTM Special Technical Publication 169, 1956, pp 334-345.

9. Sideris, Von K., "The Temperature Expansion Maximum in the AlkaliAggregate Reaction," Zement-Kalk Gips, Vol 10, No. 12, 1979, Germany, pp 508-509.

10. Mather, K., "Alkali-Reactive Quartz at Normal Temperatures," (unpublished), presented at Transportation Research Board Annual Meeting, Washington, D. C., 22 Jan 1976.

11. Gogte, B. S., "An Evaluation of Some Common Indian Rocks With Special Reference to Alkali-Aggregate Reactions," Engineering Geology, Vo1 7, Amsterdam, 1973, pp 135-153.

12. Dolar-Mantuani, L. M. M., "Undulatory Extinction in Quartz Used for Identifying Potentially Alkali-Reactive Rocks," Proceedings of Conference on Alkali-Aggregate Reaction in Concrete, 1981, paper No. S252/36, 6 pp, National Bldg. Res. Inst. of CSIR, Pretoria, S. Africa. 
13. Stark, D., "Alkali-Silica Reactivity: Some Reconsiderations," Cement, Concrete, and Aggregates, CCAGDP, Vol 2, No. 2, Winter 1980,
pp 92-94.

14. Tuthill, L. H., "Alkali-Silica Reaction - 40 Years Later," Concrete International, Vol 4, No. 4, Apr 1982, pp 32-36. 
Table 1

Length Change of Mortar Bars* With Five Embedded Pebbles at Two Temperatures

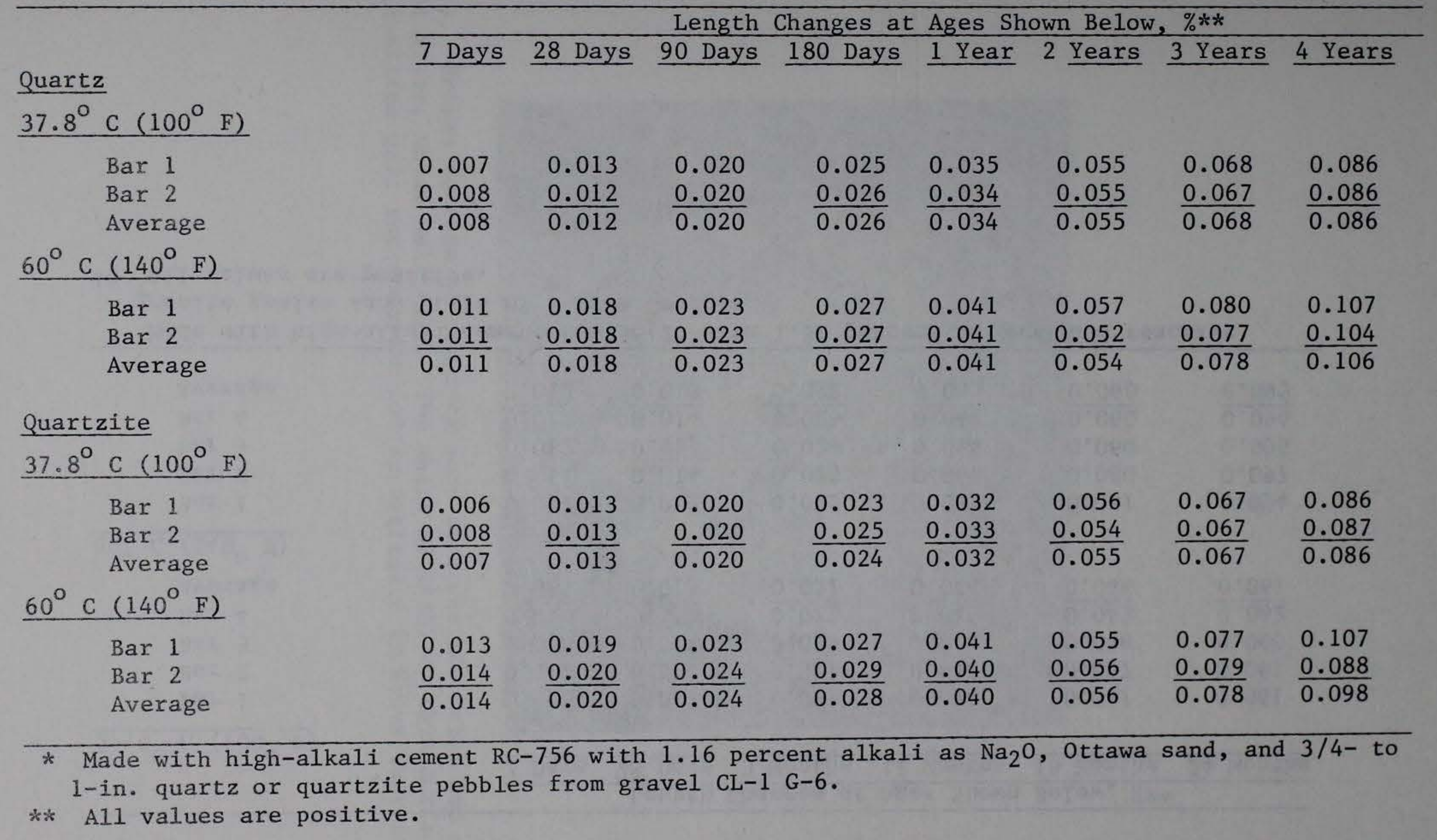


Table 2

Length Changes of Mortar Bars* Stored at Two Temperatures

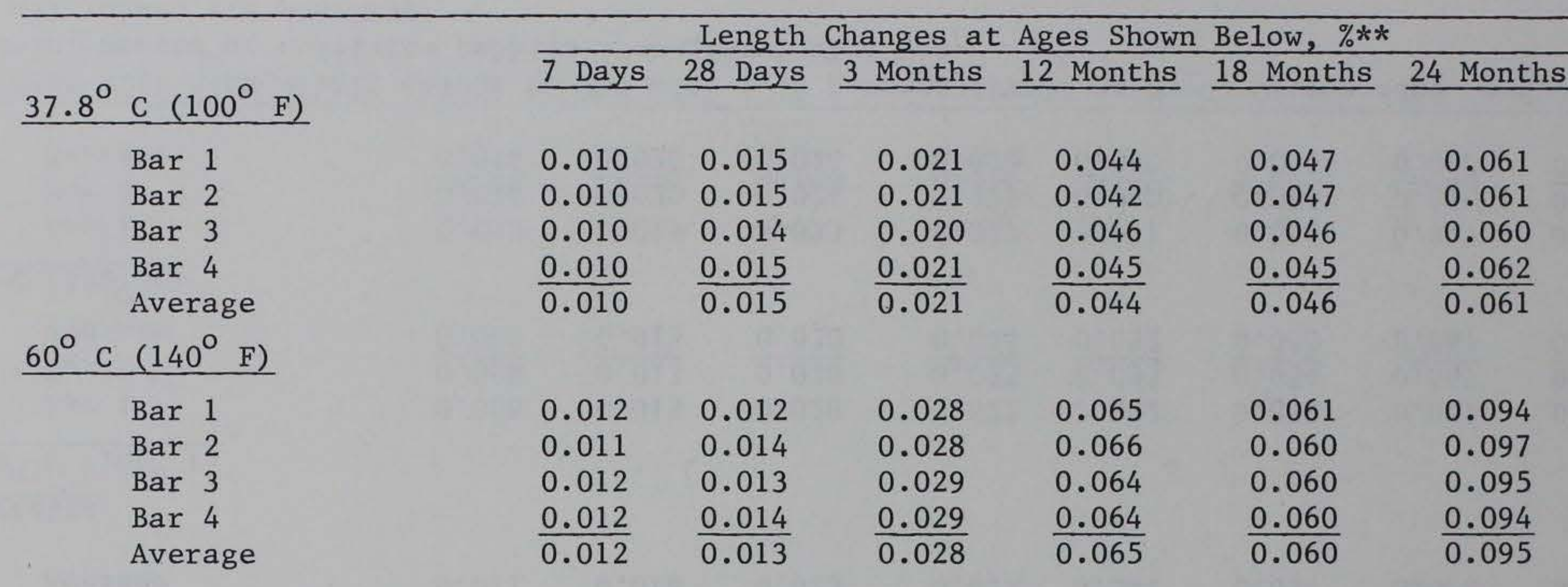

* Made with high-alkali cement RC-756(2) with 1.31 percent as Na 20 and reactive granite gneiss sand $\mathrm{CL}-14 \mathrm{MS}-1$ from Georgia.

** All values are positive. 


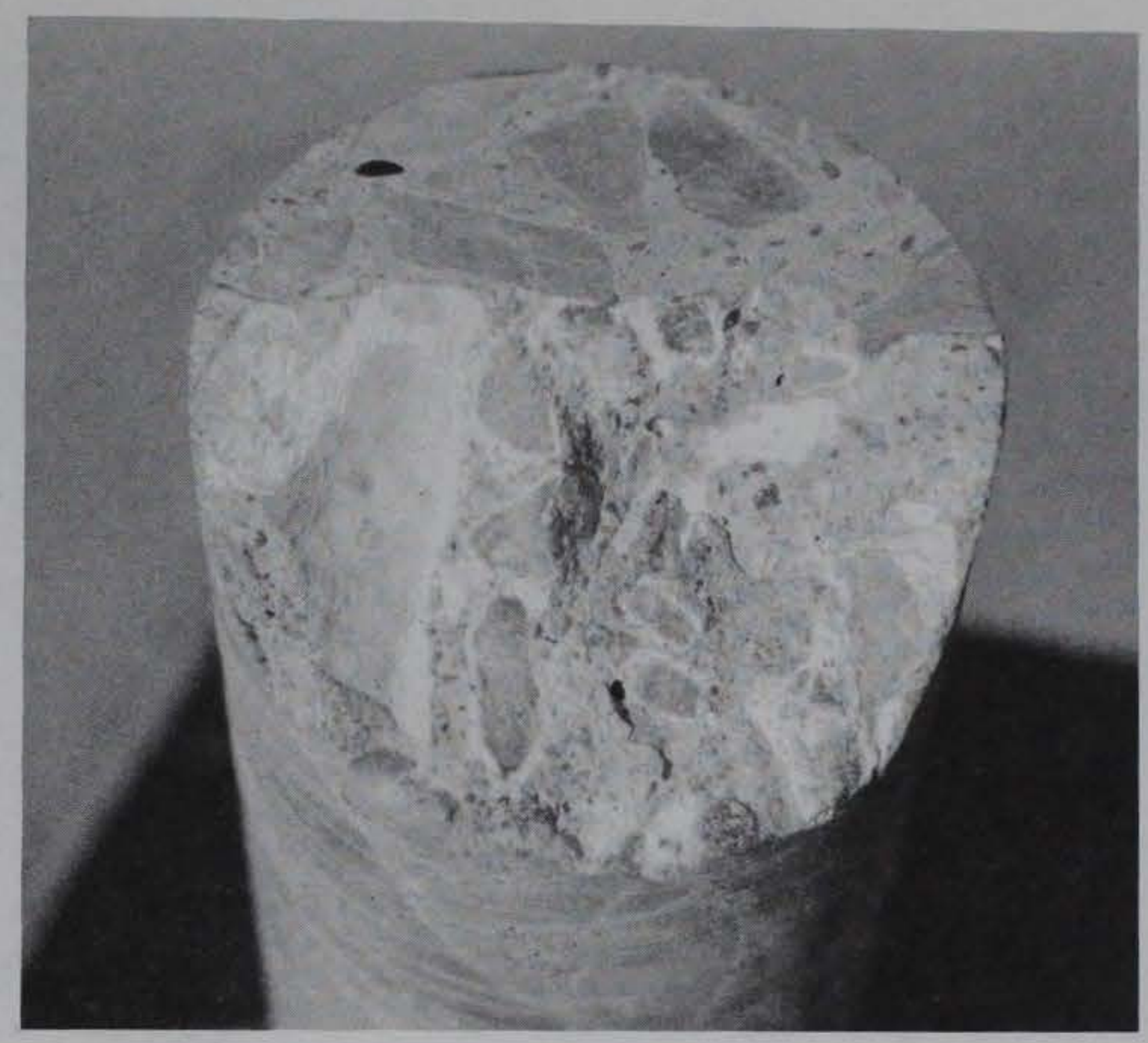

Figure 1. Broken surface of concrete core from Gavin's Point Dam on the Missouri River, about half size. The white material on this surface is alkali-silica gel; the reactive coarse aggregate is Sioux Quartzite 


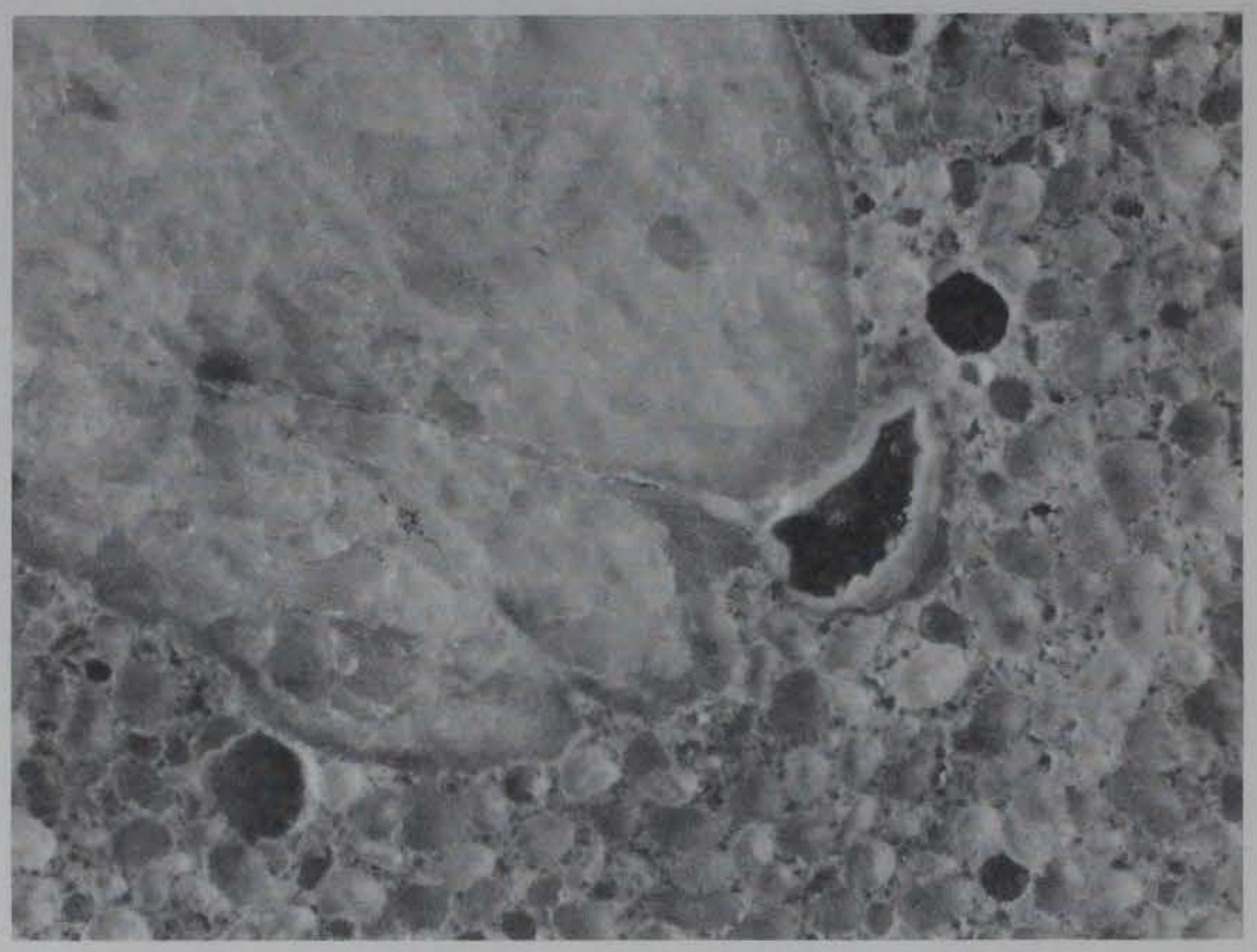

Figure 2. Sawed and ground surface of mortar bar after several years of length-change testing, X 5. Alkali-silica gel lining void at contact of rimmed and cracked quartzite pebble and mortar 